\begin{tabular}{|l|l|l||}
\hline \multicolumn{2}{|c|}{ PublisherInfo } \\
\hline \hline PublisherName & $:$ & BioMed Central \\
\hline \hline PublisherLocation & $:$ & London \\
\hline \hline PublisherImprintName & $:$ & BioMed Central \\
\hline \hline
\end{tabular}

\title{
Breast cancer gene linkage research network
}

\begin{tabular}{|l|l|l||}
\hline \multicolumn{2}{|c||}{ ArticleInfo } \\
\hline \hline ArticleID & $:$ & 3676 \\
\hline \hline ArticleDOI & $:$ & $10.1186 /$ bcr-2000-2-webreport0009 \\
\hline \hline ArticleCitationID & $:$ & 0009 \\
\hline \hline ArticleSequenceNumber & $:$ & 42 \\
\hline \hline ArticleCategory & $:$ & Web Report \\
\hline \hline ArticleFirstPage & $:$ & 1 \\
\hline \hline ArticleLastPage & $:$ & 3 \\
\hline \hline & & RegistrationDate : 2000-2-29 \\
ArticleHistory & $:$ & OnlineDate $\quad$ 2000-2-29 \\
\hline \hline ArticleCopyright & $:$ & Current Science Ltd2000 \\
\hline \hline ArticleGrants & $:$ & \\
\hline \hline ArticleContext & $:$ & 1305822 \\
\hline \hline
\end{tabular}




\section{Overview}

The Breast Cancer Linkage Consortium (BCLC) was founded in 1989 as a worldwide data-sharing platform for scientists with a research interest in breast and ovarian cancer. The focus of the group is to find breast cancer predisposition genes by linkage analysis in families with multiple cases of breast cancer. The BCLC database holds genetic data on over 700 breast cancer families from Europe, Canada and the USA, contributed by around 100 research centres. The group receives EC funding.

\section{Content}

First, a good account of the history of the consortium is given, which outlines the founding principles, main achievements, and organisational structure. The site lists BCLC's most salient accomplishments as (a) estimating genetic heterogeneity of inherited breast cancer and cumulative cancer risks conferred by the breast cancer genes BRCA1 and BRCA2, and (b) characterisation of the histopathological features of breast tumours arising in BRCA1 or BRCA2 carriers.

Next, the consortium's peer-reviewed publications are listed, with links to online abstracts (via PubMed) where available. Also listed are contact details for members of the steering committee. The consortium meets annually and the programme and abstracts from the most recent meeting can be seen on the site.

Within the 'current studies' section, there is a substantial amount of information about how the consortium works, what information is currently held in the breast cancer family database, and abstracts for all ongoing research projects. For example, studies underway at the moment include: 'Risks to cancers other than those of the breast and ovary conferred by BRCA2' and 'Characterisation of the haplotypes of recurrent BRCA1 and BRCA2 mutations ofdiverse geographical origin'.

The most important, and possibly most useful, section of the site is a summary of all data on BRCA1 and BRCA2 collated by the group. The information is summarised in graphs and tables for easy reference, and includes clinical tools to calculate, for example, the risk of breast cancer in BRCA1 mutation carriers, or risk of ovarian cancer in BRCA2 mutation carriers.

\section{Other comments}


The site was last updated between one and six months ago, depending on the page (although the nature of the site means that it doesn't require more frequent updating). The site is very simple and apart from 'home' buttons on most pages, has no intra-site navigation.

\section{Evaluation}

This site is a useful repository for data in this specific field of breast cancer research. It also describes the aims of the consortium and gives guidelines on joining or contributing to the group.

\section{References}

1. The Breast Cancer Linkage Consortium. [http://ruly70.medfac.leidenuniv.nl/ devilee/bclchome.htm] 